DOROTA ZAWORSKA-NIKONIUK

ORCID 0000-0003-3645-4939

Uniwersytet Warmińsko-Mazurski

w Olsztynie

\title{
PEDAGOGICZNE (KON)TEKSTY PLCI W FILOZOFII SIMONE DE BEAUVOIR
}

\begin{abstract}
AвSTRACt. Zaworska-Nikoniuk Dorota, Pedagogiczne (kon)teksty ptci w filozofii Simone de Beauvoir [Socialization and Educational Creed of Simone de Beauvoir]. Studia Edukacyjne nr 58, 2020, Poznań 2020, pp. 169-189. Adam Mickiewicz University Press. ISSN 1233-6688. DOI: 10.14746/se.2020.58.9

In the text offered to the reader I made an attempt to re-read the central claim presented in the work of S. de Beauvoir titled The Second Sex through the prism of lessons identified for modern upbringing. The central thesis can be described as follows: the differences between genders are socially and culturally conditioned, yet determined by belonging to biological sex; maternal instinct is culturally shaped; the mother's attitude towards the child depends on its biological sex; housework is limiting women's potential and focus on outlook causes fear of old age. The direction of change set by de Beauvoir is the androgynous upbringing of women, changing the model of marriage, conscious motherhood, women's professional work, and creation of feminine cultural communities.
\end{abstract}

Key words: Simone de Beauvoir, education towards liberation, pedagogical hermeneutics

\section{Wprowadzenie}

Sześćdziesiąt lat temu ukazała się we Francji książka zatytułowana Druga płeć, autorstwa Simone de Beauvoir, która zrewolucjonizowała poglądy na istotę kobiecości i męskości, kwestionując popularny wówczas w naukach przyrodniczych, humanistycznych i społecznych esencjalizm biologiczny ${ }^{1}$, wywołując przy tym we Francji obyczajowy skandal. Pięćdziesiąt lat później poglądy Simone de Beauvoir nie tylko nie budziły społecznego oburzenia, ale też znalazły odzwierciedlenie w pracach wiodących przedstawicieli nauk spo-

${ }^{1}$ Esencjalizm biologiczny to pogląd, który upatruje różnice między płciami w naturze. Za S. Lipstiz-Bem, Esencjalizm biologiczny, [w:] Męskość, kobiecość. O różnicach wynikajacych z płci, Gdańsk 2000, s. 19-48. 
łecznych i humanistycznych (m.in. P. Bourdieu²) oraz dominujących nurtach myśli feministycznej (np. feminizmu egzystencjalnego) ${ }^{3}$. W niniejszym tekście próbuję przybliżyć te poglądy słynnej egzystencjalistki, odnoszące się do socjalizacji i wychowania dziewcząt oraz chłopców, które zasługują na ponowne odczytanie bądź refleksję. Inspirację dla jej dzieł stanowiła filozofia egzystencjalna J.P. Sartre'a jej duchowego przewodnika i życiowego partnera.

\section{Krótka historia powstania Drugiej płci}

Filozofów egzystencjalnych, zwłaszcza J.P. Sartre', a interesowała szczególnie kwestia ludzkiej wolności, początkowo indywidualnej później zbiorowej. Kluczowym pojęciem jego filozofii była kwestia wolności, odpowiedzialności i sytuacji ${ }^{4}$ Filozofia egzystencjalna zakładała, że egzystencja poprzedza esencję:

Najpierw się żyje w określonej sytuacji, dopiero później można nadawać temu faktowi znaczenia, wybierając własny sposób bycia. Nie istnieje nic takiego, danego z góry, co dałoby się określić jako „przeznaczenie"

Ludzie są wolni, jednak nie umieją korzystać z tej wolności, posługują się kategorią „najwyższej konieczności”, która zdejmie z nich poczucie odpowiedzialności. Szukają usprawiedliwień dla własnych wyborów albo zachowują się stereotypowo, padając ofiarą społecznych konwencji - twierdził J.P. Sartre, a o swej koncepcji rozmawiał często z Simone de Beauvoir. Jaką jednak wolność może mieć kobieta zamknięta w haremie? - zastanawiała się Simone de Beauvoir, a słysząc ten niepodważalny argument Sartre rozbudowując swą koncepcję wolności, wprowadził pojęcie sytuacji. Uznał, iż wprawdzie każdy człowiek jest wolny, jednak jego wolność jest ograniczona w zależności od sytuacji w jakiej się znajduje. Wyłącznie wolność zaprzeczania, negacji, jest praktycznie nieograniczona i stanowi podstawę bytu dla siebie, bytu świadomego. Innymi słowy, pewne wyznaczniki ludzkiej kondycji są wyznaczone przez pochodzenie społeczne, przebieg biografii, przynależność narodową i płeć. I tę właśnie koncepcję płci analizować zaczęła Simone de Beauvoir:

Od pytania o wolność kobiety w haremie tylko krok do kolejnego problemu: czy bycie kobietą można uznać za sytuację? Czy fakt bycia kobietą stanowi ograniczenie wolności? Czy kobiety wolne są w ten sam sposób co mężczyźni? Ten punkt wyjścia przyjęła

\footnotetext{
2 P. Bourdieu, Męska dominacja, Warszawa 2004, s. 102.

${ }^{3}$ R. Putan Tong, Myśl feministyczna - wprowadzenie, Warszawa 2005.

${ }^{4}$ A. Nasiłowska, Jean Paul Sartre i Simone de Beauvoir, Kraków 2006, s. 9.

${ }^{5}$ Tamże.
} 
Simone de Beauvoir przystępując do pisania książki o kobietach, która ostatecznie otrzymała tytuł „Druga płeć” ${ }^{6}$.

Na początku tej książki postawiła tezę, że choć kobiety powinny być równe mężczyznom, to jednak nie są, gdyż ich wolność jest krępowana przez ogromną ilość mitów, wyobrażeń kulturowych i oczekiwań społecznych, które po kolei analizowała. One to właśnie składają się na sytuację „bycia kobietą", stąd wzięła się najistotniejsza myśl Simone: „Nie rodzimy się kobietami, stajemy się nimi". Uważała ona, że biologia utożsamiana $\mathrm{z}$ naturą nie determinuje przeznaczenia kobiety, to społeczne oczekiwania warunkują sposób socjalizacji i wychowania dziecka, w wyniku którego dziewczynkę przystosowuje się do bierności, pasywności, uległości i zależności od mężczyzn. Simone de Beauvoir pisała swe liczące prawie osiemset stron dzieło niespełna dwa lata (1946-1948). Od 1949 roku fragmenty książki były publikowane w piśmie "Les Temps Modernes” i od razu wywołały falę ataków ze strony publicystów, którzy starali się zakwestionować jej pracę. Po ukazaniu się książki drukiem we Francji okrzyknięto ją mianem "skandalicznej"7. Najbardziej kontrowersyjne było, zdaniem publicystów, podważanie przekonania, że relacje płci są ustalone raz na zawsze, a podległość kobiety słuszna i wynikająca z jej natury. W rezultacie, za napisanie najwybitniejszego dzieła swego życia Simone de Beauvoir została pod koniec lat czterdziestych odrzucona przez własną rodzinę, usunięta z miejsca pracy, znalazła się na watykańskim indeksie ksiąg zakazanych, wreszcie nieco później została zaatakowana przez feministki (dla których nie do przyjęcia była perspektywa psychoanalizy i egzystencjalizmu). Z kolei, w Stanach Zjednoczonych w latach sześćdziesiątych Druga płeć trafiła na zupełnie inny grunt społeczno-polityczny; filozofkę uznano za prekursorkę nowego feminizmu ${ }^{8}$ (obecnie wyróżnia się feminizm egzystencjalny Simone de Beauvoir), stała się wzorem osobowym dla młodego pokolenia kobiet dążących do zerwania z drobnomieszczańskim stylem życia, kształcenia się i pracy zawodowej. Apoteoza wolności zbiegła się z protestami pacyfistycznymi przeciwko wojnie w Korei, Wietnamie oraz z ideologią kontestującego ruchu hipisowskiego. Simone de Beauvoir uznała zaś Druga płeć za najwybitniejsze dzieło swojego życia.

${ }^{6}$ Tamże, s. 220.

${ }^{7}$ Na przykład, w piśmie "Action” książka została omówiona tendencyjnie, a omówienie to zilustrowano zdjęciem kobiety całującej się z małpą. Publikację tę obwołano przy tym jako niemoralną i groźną dla francuskiej rodziny, zarzucając jej epatowanie erotyzmem i deprawacje młodzieży. Podaję za: A. Nasiłowska, Jean Paul Sartre i Simone de Beauvoir, s. 222.

8 Tamże. 


\section{Główne tezy Drugiej płci}

Różnice pomiędzy płciami warunkuje sposób socjalizacji i wychowania. S. de Beauvoir pisała:

Nie rodzimy się kobietami - stajemy się nimi. Kształtu przybieranego w społeczeństwie przez samicę człowieka nie determinuje żadne przeznaczenie, biologiczne, psychiczne czy ekonomiczne (...) Tylko za pośrednictwem innych ludzi osobnik staje się Innym. Istniejąc tylko dla siebie, dziecko nie mogłoby określić swej odrębności płciowej. I u dziewczynek, i u chłopców ciało jest początkowo promieniowaniem subiektywności, i narzędziem za pośrednictwem którego pojmują świat - a świat ujmujemy przecież oczyma i rękami, nie narządami płciowymi ${ }^{9}$.

Zwracała tym samym uwagę na fakt, iż nie istnieją wrodzone różnice pomiędzy chłopcami i dziewczynkami, poza różnicami genitalnymi, co uwidacznia się w ciągu pierwszych lat życia. Noworodki męskie i żeńskie wyglądają identycznie, mają te same potrzeby i pragnienia. To środowisko rodzinne, szkolne, rówieśnicze i tym podobne w sposób mniej lub bardziej świadomy doszukuje się tych różnic i uwypukla je, kształtując dziewczynki na jednostki bierne, zależne od otoczenia, mało samodzielne i opiekuńcze; zaś chłopców jako zdecydowanych, pewnych siebie, dumnych ze swej męskości, odważnych. Za zachowania zgodne z normami przypisanymi danej płci biologicznej dzieci uzyskują wzmocnienia pozytywne, za przeciwne zaś sankcje. Ze względu na to, iż rodzice, krewni, a potem nauczyciele są dla dziecka osobami znaczącymi, starają się przypodobać dorosłym. Dziewczynka, której aktywność ruchowa jest tłumiona, podobnie jak agresja i negatywne uczucia uczy się rezygnować $\mathrm{z}$ własnego Ja:

U kobiety odwrotnie, od samego początku zarysowuje się konflikt między samodzielną egzystencją a istnieniem „dla innych"; dziewczynka dowiaduje się od dorosłych, że chcąc się podobać, trzeba się o to starać, trzeba stać się przedmiotem - musi zatem zrezygnować z samodzielności ${ }^{10}$.

Dziewczynka obserwując świat dorosłych, utożsamia się z matką, początkowo zresztą świat wydaje się jej niemal matriarchalny, kobiety opiekują się dziećmi i zarządzają gospodarstwem domowym, czuje się dumna jeśli matka powierza jej obowiązki domowe, nie zdaje sobie jednak sprawy, iż to ogranicza w znaczny sposób rozwój jej zainteresowań i zabiera czas na naukę. Chłopcy są zwalniani z obowiązków domowych, ich dzieciństwo, beztroska i swobodny rozwój trwa dłużej. Dojrzewając i dorastając, dziewczynka uświadamia sobie, iż los chłopca jest znacznie korzystniejszy niż jej

\footnotetext{
${ }^{9}$ S. de Beauvoir, Druga płeć, Warszawa 2004, s. 310.

${ }^{10}$ Tamże, s. 311.
} 
własny. Utożsamianie się z matką nie jest dla dziewczynki korzystne; ojciec wydaje się jej postacią niemal mistyczną, matka nudną, to ojciec pracuje poza domem, rodzina poprzez jego osobę komunikuje się z całym światem. Dziewczynka postrzega go jako istotę transcendentną, ziemskie ucieleśnienie Boga, bowiem od dziecka czytając mity, bajki, legendy i inne opowieści dowiaduje się, iż wszelkie istotne wydarzenia inicjowane i odgrywane są przez mężczyzn zazwyczaj nawet bez udziału kobiet. Mężczyźni fascynują ją, budzą podziw, szacunek i respekt, a także poczucie, że kobiety nie są w stanie odgrywać czynnej roli w życiu społecznym. Tożsamość młoda dziewczyna może uzyskać jedynie budząc podziw mężczyzn, ten zaś zamierza osiągnąć poprzez troskę o własną urodę, co czyni ją nacystką w późniejszym życiu, uczy przy tym oceniać swą urodę poprzez pryzmat spojrzenia mężczyzny. Istotną fazą w życiu dziewczynki jest okres buntu przeciwko matce; córce wydaje się ona nieciekawa, jest ofiarą, a jej życie składa się z biernego oczekiwania, ten bunt owocuje fascynacją postaciami mężczyzn - głównie zwracaniem się ku ojcu. Świadczy o lęku dziewczynki przed powtórzeniem matczynego losu, który ta stara się dziewczynie narzucić $\mathrm{w}$ trosce o jej dobro lub z nieuświadomionej potrzeby zemsty za swe zniweczone plany życiowe. Dziewczynka zdaje sobie sprawę, że krępuje ją płeć biologiczna, imponuje jej przebywanie w środowisku chłopców, którzy mogą w pełni aktualizować swój życiowy potencjał:

Ten sam odruch, który w pierwotnych społeczeństwach podporządkowuje kobietę hierarchii męskiej, u każdej wtajemniczonej wyraża się buntem przeciw swemu losowi. Transcendencja w kobiecie potępia absurdalność i immanencję. Denerwuje się, że musi liczyć się z względami przyzwoitości, że ją krępują suknie, że jest obarczona pracami domowymi, wstrzymywana we wszystkich swych porywach (...) Dziewczynki cierpią odczuwając to jako krzywdę i niesprawiedliwość; poza tym narzucony im tryb życia jest bardzo niezdrowy. Ich żywotność ulega zahamowaniu, niezużyte siły przemieniają się w nerwowość, nazbyt spokojne zajęcia nie wyczerpują nadmiaru energii i dlatego zaczynają się nużyćc ${ }^{11}$.

Jedynym zajęciem, które proponuje się kobiecie jest oczekiwanie na mężczyznę, to powoduje, że dorastające dziewczęta zaczynają fantazjować, utwierdzając się w bierności, ku której skłania poświęcanie czasu fantazjom, układają w wyobraźni scenariusze romansów i tkwią w poczuciu litości nad samymi sobą, w rezultacie dorastają na kokietki, komediantki i nacystki:

Urojenia, komedie, dziecinne tragedie, fałszywe entuzjazmy, dziwactwa - a przyczyn tego wszystkiego należy szukać nie w jakiejś tajemniczej kobiecej duszy, lecz w sytuacji dziecka. Bo cóż to za dziwne przeżycie dla jednostki, odczuwającej siebie samą jako podmiot, autonomię, transcendencję, absolut - kiedy odkrywa w sobie niższość

11 Tamże, s. 312. 
jako immanentną esencję; cóż to za dziwne przeżycie dla kogoś, kto odczuwa siebie jako Jedność, kiedy odkrywa w sobie Inność. A to właśnie zachodzi z dziewczynką, kiedy poznając świat, widzi w nim siebie jako kobietę. Krąg, do którego należy, jest ze wszystkich stron zamknięty, ograniczony, opanowany przez męski świat ${ }^{12}$.

To sytuacja życiowa kobiety wyznacza jej los i kształtuje cechy charakteru, te same które stają się później przyczynkiem do kpin z rzekomo „kobiecej natury". O dojrzałych kobietach S. de. Beauvoir pisze:

Ich złe samopoczucie znajduje wyraz w zniecierpliwieniu, atakach wściekłości i płaczu; płaczą tak chętnie - niektórym kobietom pozostaje to na całe życie - głównie dlatego, że lubią udawać ofiary; jest to zarazem protest przeciwko bezwzględności losu u sposób aby wydać się wzruszającą ${ }^{13}$.

Tradycyjne małżeństwo służy interesom społeczeństwa a nie jednostki. W czasie kiedy powstawała Druga płeć, wśród środowisk mieszczańskich małżeństwo i nieodzownie z nim związane macierzyństwo traktowano jako nieuchronne przeznaczenie kobiety, nadzieję na dostatnią przyszłość i ekonomiczną karierę. Sama filozofka uznawała tradycyjne małżeństwo za formę nierówności społecznej; mężczyzna często dojrzały posiadający seksualne doświadczenia i mający ugruntowaną pozycję w życiu publicznym „brał za żonę" młodą dziewczynę, nie posiadającą często własnej tożsamości, której podstawowym kapitałem było ciało, ona zaś sama nie zdołała w życiu doświadczyć ani osiągnąć niczego. Utrzymywał ją, a obowiązek zapewnienia kobiecie utrzymania motywował go do wytężonej pracy, tym samym podnoszenia zawodowej pozycji. Usprawiedliwieniem społecznym egzystencji kobiety zdawało się prowadzenie domu i wychowywanie dzieci, te czynności nie cieszą się jednak społecznym prestiżem, a ponadto odbierają radość życia monotonią. Kobieta zamknięta $\mathrm{w}$ domu, ograniczona do roli żony i matki, kompensowała sobie zatem za pomocą nabywania przedmiotów służących do upiększania domu swą niemożność zaistnienia $\mathrm{w}$ świecie publicznym oraz stłumioną zmysłowość ${ }^{14}$. Otaczanie się przedmiotami oraz wykonywanie prac domowych nadawały cel jej życiu, dlatego nie pozwalała pomagać sobie w tych czynnościach. Aby sensu tego nie utracić, starała się uzależnić od siebie psychicznie męża i dzieci, a poprzez pracę na ich rzecz zapewnić sobie minimum władzy. Mężczyzna z kolei próbował sprawować władzę intelektualną i duchową nad żoną, komentując sytuację polityczną, podkreślał niższość kobiet, używał apodyktycznego tonu, a samodzielność kobiet zdawała mu się buntem. Gospodyni domowa buntuje się jednak inaczej, służy temu

\footnotetext{
12 Tamże, s. 328.

13 Tamże.

14 Tamże, s. 490.
} 
oziębłość seksualna lub zgadzanie się pokorne na swój los, by manipulacją i przekupstwem utrzymywać męża przy sobie. Tego typu małżeństwo służy państwu i społeczeństwu, nie zapewnia jednak szczęścia osobistego ani kobiecie, ani mężczyźnie. Kobieta zależna ekonomicznie od męża będzie próbowała go dominować i tyranizować, gdyż od jego pozycji i zarobków zależy los jej oraz jej potomstwa ${ }^{15}$. Małżeństwo takie porównuje z niewolą wypaczającą psychikę kobiety i mężczyzny:

Niewola małżeńska jest najbardziej powszednia i bardziej irytująca dla męża, ale głębsza dla żony, która godzinami trzyma męża przy sobie bo się nudzi, ogranicza go i ciąży mężczyźnie, ale ostatecznie mąż może łatwiej obejóć się bez żony, niż ona bez niego; jeżeli on ją porzuci jej życie zostanie zmarnowane ${ }^{16}$.

W wyniku zależności od męża i dzieci, wykonywania nudnych czynności, braku rozwoju umysłowego wyzwalają się niekorzystne zachowania kobiety, które później znajdują wyraz w aforyzmach, powieściach i tym podobnych. Kobiety gderają, stają się despotycznymi matronami, zachowują narcystycznie, popadają $\mathrm{w}$ depresje, melancholie, marzą, zamykają się $\mathrm{w}$ świecie fantazji. S. de Beauvoir uważała, iż kobietę i mężczyznę okalecza sama instytucjonalizacja małżeństwa, a nie współbycie w związku. Prawdopodobnie dlatego też sama nie zdecydowała się nigdy na małżeństwo z J.P. Sartre'em, zamieszkiwanie z nim, ani prowadzenie domu. Opowiadała się za związkami kobiet i mężczyzn dobrowolnymi (nie aranżowanymi), tworzonymi przez wolne, równouprawnione istoty ludzkie:

Aby między mężem i żoną mogła istnieć lokalność i przyjaźń, musi zachodzić jeden warunek sine quo non: mianowicie muszą być oboje wobec siebie wolni i faktycznie równi ${ }^{17}$.

Dostrzegała różne rodzaje związków: koleżeńskie, otwarte seksualnie, oparte na przyjaźni, uczuciu i relacji seksualnej, najistotniejsza była w nich jednak wolność. Małżeństwo, związek partnerski, kohabitacyjny i tym podobny powinno wspólistnieć $\mathrm{w}$ społeczeństwie, a nie izolować się od niego w zaciszu domowego ogniska, a kobieta i mężczyzna nie mogą ograniczać swych potrzeb ani upodobań. Wszelkie nierówności w związku pomiędzy dwoma istotami szkodzą im obu, szkodzą nawet tym - w tym wypadku mężczyznom, którym zdaje się, iż są uprzywilejowani, gdyż kobiety zmieniają się charakterologicznie starając zemścić na nich za swój nieudany los.

\footnotetext{
15 Tamże, s. 528

16 Tamże, s. 538.

17 Tamże, s. 523.
} 
Instynkt macierzyński jest kształtowany kulturowo, macierzyństwo nie gwarantuje spełnienia. Najwięcej kontrowersji budziły poglądy Simone de Beauvoir dotyczące kwestii macierzyństwa. Sama filozofka nie zdecydowała się nigdy zostać biologiczną matką, a z lektury Drugiej ptci można wnioskować, że pewna "samiczość" macierzyństwa (jak karmienie piersią, przewijanie itp.) budziła w niej skrajne uczucia. Niekonsekwencje w podejściu do małżeństwa i macierzyństwa uwidaczniają się w biografii Simone de Beauvoir. Jak pisze Małgorzata Domagalik:

Ten rodzaj niekonsekwencji motywował ją do ciągłych zmian i łamania kulturowych tabu. Rano chciała być samotnicą, a już wieczorem była pewna, że „wszystko czego pragnęła, to miłości, pisania dobrych książek i posiadania kilkorga dzieci"18.

Wiele lat później jednak pytana o życie prywatne uznała w rozmowie z Alice Schwarzer, że macierzyństwo jest formą niewolnictwa, a kobiety mające dzieci ulegają społecznej mistyfikacji i kulturowej presji ${ }^{19}$. W jej pracach pojawia się jednak teza, iż świadome macierzyństwo dojrzałej kobiety, która zrealizowała już inne życiowe cele może zapewnić jej szczęśliwe życie. Walka o upowszechnianie idei świadomego macierzyństwa przejawiała się w codziennym życiu Simone de Beauvoir. Włączyła się ona do organizowanej we Francji akcji „Miałam aborcję” w 1971 roku podpisując słynny list 343 Francuzek, angażując się czynnie w ruch „Pro-choice”. W przeciwieństwie do innych feministek traktuje aborcję jako wielki, moralny dramat kobiety, który może mieć negatywne skutki psychiczne dla jej dalszego życia:

Nawet jeśli to nieprawda, że spędzanie płodu jest dzieciobójstwem, nie można go również utożsamiać ze zwykłymi praktykami antykoncepcyjnymi: zaszło tu bowiem coś co jest absolutnym początkiem i czego rozwój zostaje wstrzymany ${ }^{20}$.

Dziewczynka od najmłodszych lat jest jej zdaniem socjalizowana i wychowywana ku macierzyństwu, społeczna presja zostania matką jest tak wielka, że nie sposób oddzielić byłoby tego co wrodzone od tego co nabyte kulturowo, dlatego kwestionuje tezę o bezwzględnym istnieniu instynktu macierzyńskiego u ludzi:

W każdym razie nie można stosować tego terminu do rodzaju ludzkiego. Postawę matki określa całokształt jej sytuacji i sposób, w jaki tę sytuację przyjmuje; jak widzieliśmy bywa on nader różnorodny. Jest jednak niezaprzeczalnym faktem, że jeśli okoliczności nie są szczególnie niesprzyjające dziecko wzbogaca życie matki ${ }^{21}$.

\footnotetext{
${ }^{18}$ M. Domagalik, Przedmowa, [w:] S. de Beauvoir, Druga pteć, s. 14.

19 A. Schwarzer, Simone de Beauvoir, Chatto \& Windus 1990.

20 S. de Beauvoir, Druga płeć, s. 547.

${ }^{21}$ Tamże, s. 569.
} 
Uważa, że społeczeństwo odmawiające kobietom prawa do równouprawnionego decydowania o swych losach (choć w sposób nieco zawoalowany), traktując je i co gorsza często również kształtując na istoty infantylne, mało wykształcone i neurotyczne, a z drugiej strony powierza misję wychowywania nowych istot ludzkich, jest głęboko niekonsekwentne:

Godzić pogardę dla kobiet z czcią dla matek - oto dowód wyjątkowej nieszczerości. Cóż to za zbrodniczy paradoks: odmawiać kobiecie prawa do jakiejkolwiek działalności publicznej, zamykać przed nią drogi do męskich zajęć, głosić jej nieudolność we wszystkich zawodach - a przy tym wszystkim powierzać jej najdelikatniejszą i najpoważniejszą zarazem sprawę jaką jest kształtowanie człowieka ${ }^{22}$.

Macierzyństwo nie musi być celem życia kobiety; wokół niego narosło - zdaniem Beauvoir - sporo stereotypów: dzieci nie stanowią źródła największego spełnienia, gdyż jest zbyt wiele nieszczęśliwych matek, ponadto dziecko nie może być źródłem największego spełnienia, a jego wychowanie jedynym celem życia matki, gdyż ta przeniesie wówczas na niego wszelkie swoje frustracje. Stosunek matki do dzieci jest określony jej doświadczeniami życiowymi, stosunkiem do męża, własnej przeszłości, siebie. Kobieta chcąc zostać matką, musi być istotą dojrzałą moralnie, materialnie, psychologicznie, dziecko zaś powinno być upragnione dla niego samego. Macierzyństwa nie poleca zwłaszcza melancholiczkom, neurasteniczkom i kobietom cierpiącym na depresję. Zwraca uwagę na fakt, iż niska pozycja społeczna kobiet wpływa negatywnie na rozwój ich dzieci, na których kobieta zaczyna odgrywać się za swój „zmarnowany los", co może prowadzić do aktów przemocy. Niska pozycja kobiet i ich podporządkowanie mężczyznom może spowodować, iż one same będą podporządkowywać sobie i dominować dzieci. Wyjściem z tej sytuacji jest decydowanie się na macierzyństwo kobiet spełnionych życiowo oraz dojrzałych mentalnie. Choć - jak już wspomniałam po lekturze prac filozofki - można odnieść wrażenie, że nie doświadczała potrzeby macierzyństwa, zdawała sobie sprawę, jak cenną wartość dla kobiety może stanowić jego doświadczanie. Aby kobieta w pełni doświadczała macierzyństwa, konieczne było pragnienie dziecka dla niego samego, a nie wynikające z pobudek egoistycznych bądź kulturowej presji oraz możliwość jej samorealizacji na innych płaszczyznach ${ }^{23}$. Kobieta powinna budować własną odrębną tożsamość, pracować zawodowo, angażować się w życie publiczne, polityczne, a nader wszystko zdobywać solidne wykształcenie ${ }^{24}$. Może dać życie tylko wówczas, kiedy ma ono jakiś sens, tylko to pozwoli jej ukształtować wolnych, myślących, zdrowych ludzi. Istotne jest wspieranie kobiet matek w miejscu

\footnotetext{
22 Tamże, s. 583.

23 Tamże, s. 581

24 Tamże, s. 584
} 
pracy, ułatwiające aktywizację zawodową kobiet, co wymaga określonej organizacji społeczeństwa i osłony socjalnej macierzyństwa.

Stosunek matki do dziecka zależy od jego płci biologicznej. „Upośledzona sytuacja życiowa kobiet" wywiera istotny wpływ na stosunek matki do dziewcząt i chłopców. Pragnieniem kobiety jest posiadanie syna, aby poprzez jego osobę osiągnąć to, co niemożliwe jest jej samej jako kobiecie. W ten sposób kobieta rodząc syna, zyska społeczny prestiż, sobie zaś zapewni rodzaj duchowej nieśmiertelności ${ }^{25}$. Inaczej dzieje się, kiedy kobieta rodzi córkę. Postrzega ją wówczas jako następczynię i kontynuatorkę własnych losów, chce przeżyć życie ponownie poprzez „życie życiem córki”. Matka - jak pisze S. de Beauvoir - może przybrać wobec córki postawy trojakiego typu: podporządkować ją sobie, wykazywać nadmierną opiekuńczość i poświęcenie lub wrogość, a którą spośród nich będzie przejawiać zależy od zadowolenia z życia jej samej. Matka, która nie zrealizowała swego potencjału, niezadowolona ze swego życia będzie próbowała podporządkować sobie córkę, pozbawić ją rozrywek i zabaw, a uczyni to z zazdrości o przemijającą młodość, miłość męża (taka matka postrzega córkę jako rywalkę i staje się zazdrosna o miłość męża) i tym podobne. Niektóre matki mają poczucie winy, że wydały na świat córki, a nie synów i wówczas stają się wobec nich nadopiekuńcze. Nadmiernie poświęcające się matki nienawidzą "kobiecego losu”, toteż starają się narzucić go córce lub poprzez obranie przez córkę innego stylu życia odkupić swój los ${ }^{26}$. Córki tych matek muszą jak najszybciej uwolnić się od tak przejawianej „macierzyńskiej miłości”, co czynią przeważnie wychodząc za mąż i rodząc własne dzieci. Owocuje to jednak nieustannym życiem w poczuciu winy, że opuściła matkę. Simone de Beauvoir analizowała głównie nieprawidłowe postawy matek wobec dzieci, jednak podkreślała, że niektóre kobiety są doskonałymi matkami, zapewniającymi dzieciom wolność i niezależność. Prawidłowość ta dotyczyła tych matek, które same czuły się wolne i szczęśliwe w życiu.

Prace domowe ograniczają potencjał kobiety, a dom staje się więzieniem. Kolejnym powodem, dla którego S. de Beauvoir nie zdecydowała się na zalegalizowanie swego związku z J.P. Sartre'em był jej stosunek do prac domowych. Uważała, że w małżeństwie kobieta zawsze zaczyna w pewnym momencie podejmować czynności opiekuńczo-usługowe wobec mężczyzn, tracąc $\mathrm{w}$ ten sposób czas, który może przeznaczyć na naukę bądź pracę. Dlatego, nie dążyła do zbudowania tradycyjnego domostwa, często mieszkała w hotelach, jadała w barach lub restauracjach. Dom staje się dla kobiety wię-

\footnotetext{
25 Tamże, s. 577.

26 Tamże.
} 
zieniem, prace domowe męczą ją, nużą swą monotonią i nietrwałością, ograniczają horyzonty kobiety, gdyż niemożliwe jest ich zakończenie. Przyrządzone jedzenie zostaje od razu zjedzone, a umyta podłoga zadeptana i w rezultacie, po ich wykonaniu, gospodyni domowa rozpoczyna wykonywanie od początku. Życie domowe choć nudne nie zapewnia kobiecie bezpieczeństwa, obawia się tego co dzieje się w życiu społecznym, gdyż nie ma na nie wpływu. Boi się katastrof, kradzieży, utraty bliskich i wojen. Poprawia sobie nastrój licznymi skargami, jej stosunek do mężczyzn oscyluje pomiędzy szacunkiem, poddaństwem, lękiem a nienawiścią, jednak większość kobiet nie próbuje się buntować ani zmienić swego życia:

W większości wypadków nie chce pogodzić się z losem; wie że to co się z nią dzieje, dzieje się wbrew jej woli. Nie śmie się buntować, ale poddaje się niechętnie; jej postawa jest bezustanną skargą. Wszyscy, którzy słuchają kobiecych zwierzeń - lekarze, duchowni, opiekunki społeczne - dobrze wiedzą, że najbardziej charakterystyczną postawą kobiet jest narzekanie, w towarzystwie przyjaciółek każda narzeka na swoje osobiste zmartwienia, a wszystkie razem - na niesprawiedliwość losu, na świat mężczyzn w ogóle ${ }^{27}$.

Bierność i zależność od innych, ku którym kobieta jest socjalizowana, zniechęca ją do buntu. Poprzez sprawowanie władzy w domu staje się sprawować władzę nad mężczyzną, traktuje to jako formę zemsty za swój los. Próbuje „obrzydzić” życie innym za to, że świat urządzono bez niejej. W rezultacie, często winą obarcza męża, on jest głównym reprezentantem męskiego świata, najbliższym domowemu zaciszu. To poczucie niesprawiedliwości i wzbudzanie w nim poczucia winy przywiązuje go do niej. Gospodyni domowa staje się łatwo męczennicą, każe mężczyźnie czekać, by pokazać, iż ona czeka na zmianę całe życie, jest to jedyna forma władzy, którą kompensuje sobie brak władzy w świecie, staje się rozrzutna, gdy mąż jest oszczędny i tym podobne.

Troska o ciało wywołuje nieustanny lęk przed starością. Również pielęgnacja urody ogranicza kobietę. Przesadna troska o wygląd była traktowana przez Beauvoir jako kompensacja niskiej pozycji w życiu publicznym i jako próba dowartościowywania samej siebie, zwłaszcza gdy kobieta nie ma innych osiągnięć. Pozbawiona tożsamości kobieta wyraża ją strojem:

Pielęgnowanie urody, strojenie się jest pewnego rodzaju pracą, która pozwala kobiecie przyswoić sobie własną osobę, podobnie jak przyswaja ona sobie dom poprzez pracę gospodarską. Własna osobowość wydaje się wówczas kobiecie wybrana i odtworzona przez jej wygląd ${ }^{29}$.

\footnotetext{
27 Tamże, s. 661.

${ }^{28}$ Tamże.

${ }^{29}$ Tamże, s. 586.
} 
Zdaje sobie jednak sprawę, iż kobieta nie jest w stanie zrezygnować z pielęgnacji wyglądu, choćby dlatego że przez atrakcyjności i seksualności ocenia ją społeczeństwo. Chcąc osiągnąć cokolwiek w życiu osobistym bądź publicznym, kobieta podlega kulturowej presji „bycia atrakcyjną”. Socjalizowana i wychowywana od najmłodszych lat na osobę, która podlega ocenie za walory zewnętrzne, zaczyna postrzegać siebie w zależności od tego, czy podoba się innym. Tożsamość kobiety oparta jest na urodzie; ona pozwala jej zdobyć męża, tym samym zapewnić sobie utrzymanie, możliwość reprodukcji potomstwa i zdobycia wyższej pozycji społecznej niż niezamężne koleżanki ${ }^{30}$. Strach przed starzeniem się, utratą urody, utratą płodności towarzyszy jej nieustannie, popada $w$ kolejną rutynę - rutynę zabiegów pielęgnacyjnych, chroniących przed upływem czasu ${ }^{31}$. W rezultacie, kobieta znajduje się nieustannie w konflikcie sama ze sobą. Najbardziej obawia się starości kobieta nadmiernie poświęcająca się innym, postrzega ona swe życie jako zmarnowane, obawia się, iż zostanie „żywym trupem”, jej ciało nie wróży już żadnych obietnic, a niespełnione sny i pragnienia pozostaną na zawsze niezrealizowane. Rozpamiętuje minione romanse, odżywa w niej tęsknota do braci i sióstr, afiszuje się osobowością, którą w sobie po latach odkryła. Próbuje zatrzymać czas: urodzić dziecko, znaleźć kochanka, podobać się innym. Lęk przed starzeniem i dążenie do zachowania młodości powoduje infantylizację tych spośród starzejących się kobiet, które nie akceptują swojej starości. Nawet jeśli kobieta akceptuje starość, aseksualność i klimakterium, musi walczyć o utrzymanie swego miejsca na ziemi. Wykorzystując swą starość, unika wykonywania domowych obowiązków, których nigdy nie lubiła, odrzuca zaloty męża pozostając przyjazna, obojętna lub wroga i urządza sobie życie obok jego życia, nie zaś z nim. Przestaje się liczyć z wymogami mody i urody, uchyla się od diety i pielęgnacji swego ciała, jednak wówczas nie odzyskuje utraconej wolności. „Uwolniona od obowiązków, odnajduje wreszcie wolność, w momencie kiedy nie może z niej już zrobić użytku"32 - zauważa de Beauvoir. W rezultacie, nie mając celu w życiu, próbuje zajmować się wnukami lub angażować w działalność publiczną. Jeśli zaakceptuje to, iż wnuki nie są jej dziećmi i nie będzie próbowała emocjonalnie zastąpić im matki, ma szansę na samorealizacje jako babcia. Zaangażowanie kobiet w kampanie charytatywne także stanowi pewien sposób na zapewnienie sobie zajęcia w podeszłym wieku. Pogodę ducha może kobieta odnaleźć dopiero pod koniec życia, przeważnie odnajdując się w domu, jeśli jej mąż przechodzi na emeryturę, przejmując domowe rządy.

\footnotetext{
30 Tamże, s. 635.

31 Tamże, s. 594.

${ }^{32}$ Tamże, s. 642.
} 


\section{Ku wyzwoleniu kobiet, czyli kierunki zmian wyznaczone przez S. de Beauvoir - wnioski pedagogiczne}

Androgyniczny model socjalizacji i wychowania. Podstawową drogą prowadzącą do wyzwolenia kobiet jest zbliżony sposób socjalizacji oraz wychowania dziewcząt i chłopców. S. de Beauvoir opowiadała się za "chłopięcym" modelem socjalizacji dziewcząt i odrzuceniem męskiego modelu socjalizacji chłopców. Istotne było zwłaszcza kształtowanie aktywności fizycznej, niezależności, odwagi dziewcząt i staranne ich kształcenie, aby małżeństwo oraz macierzyństwo nie było główną ofertą ról społecznych proponowanych młodej kobiecie, wyrabianie $\mathrm{w}$ dziewczętach poczucia odpowiedzialności za swój los i czyny, wzbudzanie ich zainteresowań nauką, kulturą, literaturą, sztuką, sportem i tym podobnymi, a także stwarzanie możliwości rozwoju. Niedopuszczalne - zdaniem filozofki - było nadmierne absorbowanie dziewcząt obowiązkami domowymi i koniecznością opieki nad młodszym rodzeństwem, zwłaszcza przy zwalnianiu z nich chłopców. Wszelkie niedogodności ograniczające aktywność życiową kobiety (m.in. bóle menstruacyjne, związane z menopauzą itp.) proponuje ona łagodzić i nie przywiązywać do nich nadmiernej uwagi. Ciążę należy natomiast traktować jako stan fizjologiczny, a nie chorobę, która nie powinna ograniczać aktywności umysłowej kobiety.

Obalanie kulturowych mitów i ukazywanie roli kobiet w nauce. Ważny krok stanowi eksponowanie roli kobiet w nauce. Pierwsza część Drugiej płci poświęcona jest ukazaniu wykluczania kobiet z kultury. Co interesujące, w pewien sposób wykluczana jest również sama Simone de Beauvoir. W podręcznikach do filozofii (m.in. W. Tatarkiewicza) autorzy nie omawiają jej koncepcji, feminizm egzystencjalny rzadko opisywany jest $\mathrm{z}$ kolei $\mathrm{w}$ analizach feministycznych. Wiele uwagi poświęcała Beauvoir twórczości kobiet artystek. Uznawała ona, że ich prace są zbyt ostrożne i zachowawcze, jakby tym „ugrzecznieniem płaciły dług wdzięczności za to, że pozwala im się tworzyć” ${ }^{\prime 3}$, trudno im zatem stworzyć coś naprawdę oryginalnego. Jak pisze:

Sztuka, literatura, filozofia to próby stworzenia nowego świata, opartego na ludzkiej wolności - wolności twórcy. Trzeba najpierw wystąpić jednoznacznie w roli wolnej jednostki, by móc żywić podobne aspiracje ${ }^{34}$.

Sztuce przypisuje jednocześnie ogromne możliwości w kwestii wyzwalania kobiet, zachęca je zatem do twórczości:

\footnotetext{
${ }^{33}$ Tamże, s. 762.

${ }^{34}$ Tamże, s. 764.
} 
Istotnie, by stać się twórcą, nie wystarczy się rozwijać, to jest wchłaniać oczyma i duchem widowiska i wiadomości. Kulturę musi przyswajać swobodny ruch transcendencji; duch z całym swoim bogactwem musi się wzbijać w puste niebo, by je zaludnić; jeśli wiążą go z ziemią tysięczne cieniutkie nici powiew zostaje wstrzymany ${ }^{35}$.

Pomijanie osiągnięć kobiet w sztuce pod pretekstem tego, że ich sztuka jest gorsza niż tworzona przez mężczyzn wynika z nieznajomości mechanizmów społecznych. Trudno określić jaki potencjał mają kobiety, skoro nie są wolne, brakuje im odwagi, kontaktu z realnym światem, a nie intelektu czy możliwości. Potencjał ten - jak pisze - będzie możliwy do określenia dopiero wówczas, kiedy na swe barki ciężar świata wezmą kobiety, gdy staną się one zupełnie wolne.

Dopiero wówczas, gdy godność człowieka nie będzie zależała od zróżnicowania seksualnego, gdy wszyscy będą żyli w trudnej chwale własnego swobodnego istnienia - dopiero wówczas kobieta będzie mogła utożsamić swą historię, problemy, wątpliwości i nadzieję z historią, problemami, wątpliwościami i nadziejami ludzkości. Dopiero wówczas zacznie odkrywać przez swoje życie i swoją pracę - całą rzeczywistość, a nie tylko własną osobę. Dopóki jeszcze walczy, by zostać człowiekiem nie może być twórcą ${ }^{36}$.

Zmiana modelu małżeństwa. Aby małżeństwo było szczęśliwe, musi być zawarte pomiędzy dwiema wolnymi jednostkami, nie może stanowić dla kobiety sposobu na zapewnienie sobie utrzymania.

Aby między mężem i żoną mogła istnieć lojalność i przyjaźń, musi zachodzić jeden warunek sine quo non: mianowicie muszą być oboje wobec siebie wolni i faktycznie równi. Dopóki tylko mężczyzna ma niezależność ekonomiczną i posiada - zgodnie z prawem i tradycją - przywileje, które daje mu męskość, dopóty jest całkiem naturalne, że tak często bywa tyranem, czym prowokuje żony do buntu i przebiegłości ${ }^{37}$.

Wypaczona była jej zdaniem instytucja małżeństwa, a nie związek kobiety i mężczyzny. Relatywnie bliższe jej życiowej filozofii były niezalegalizowane prawnie i sakralnie związki konkubinackie, otwarte na kwestie erotyki, wspierające się w codziennym życiu.

Mąż i żona nie powinni uważać się (...) za zamkniętą komórkę; jednostka jako taka powinna być częścią społeczeństwa, wewnątrz którego mogłaby się rozwijać bez pomocy, a wówczas, w atmosferze idealnej wspaniałomyślności, będzie mogła zadzierzgnąć więzy z inną jednostką, również przystosowaną do kolektywu, więzy oparte na uznaniu obu wolności. Taka zrównoważona para małżeńska nie jest utopią. Bywają takie nawet i w ramach małżeństwa, ale najczęściej poza nim. Niektóre łączy wielka miłość seksualna, pozostawiająca im jednak wolną rękę w wyborze przyjaźni i zajęć;

\footnotetext{
35 Tamże, s. 765.

36 Tamże, s. 766.

37 Tamże, s. 523.
} 
inne znów łączy przyjaźń, nie krępując swobody seksualnej; rzadziej trafiają się stadła, w których partnerzy są kochankami i przyjaciółmi zarazem, nie widząc jednak w sobie nawzajem jedynej i wyłącznej racji życia. W stosunkach między mężczyzną i kobietą możliwe jest mnóstwo odcieni, w atmosferze koleżeństwa, rozkoszy, zaufania, czułości, wspólnoty czy miłości mogą być nawzajem dla siebie najgłębszym źródłem radości, bogactwa i siły ${ }^{38}$.

Podstawą zmiany sytuacji kobiet jest zmiana instytucji małżeństwa; wykluczyć należy zwłaszcza małżeństwa aranżowane i małżeństwo jako ekonomiczną karierę kobiety. Simone de Beauvoir zauważała, iż zmiana ekonomicznej sytuacji kobiet wstrząśnie od podstaw instytucją małżeństwa, które stanowić będzie dobrowolny związek niezależnych istot. Opowiadała się za starannym planowaniem rodziny, małodzietnością kobiet, ogólną dostępnością rozwodów w przypadku małżeństw nieudanych, równouprawnieniem $\mathrm{w}$ wykonywaniu prac domowych lub zlecaniu ich odpowiednim instytucjom.

Wolność reprodukcyjna i dobrowolne świadome macierzyństwo. Simone de Beauvoir opowiadała się za świadomym macierzyństwem, propagowała antykoncepcję i dopuszczalność aborcji. Czynnie włączała się w akcje domagające się legalizacji przerywania ciąży, choć w przeciwieństwie do innych feministek uważała, że decyzja ta może być osobistym dramatem kobiety. Potępiała jednak nakłanianie kobiet do aborcji wbrew ich woli przez mężczyzn bądź matki, obawiające się opinii publicznej związanej z narodzinami „nieślubnego dziecka”. Sama kilkukrotnie przyznała się do usunięcia ciąży, choć te „ujawnienia się" po latach okazały się fikcyjne, a służyć miały wyłącznie zalegalizowaniu zabiegów, które prywatnie uważała za ogromny dramat dla kobiety (pomimo że kobieta powinna mieć do nich prawo). Uważała, że kobieta ma takie samo prawo do rozkoszy zmysłowej jak mężczyzna, a oziębłość kobiet wynikać może z niezrozumienia potrzeb seksualnych i psychiki kobiety. Istota, która nie jest wolna i niezależna nie może być zmysłową kochanką. Kontrowersje budziła pisząc o seksualizmie kobiet w podeszłym wieku, gdyż temat ten owiany był kulturowym tabu. Uważała, że niezależność ekonomiczna i praca zawodowa kobiet zmienią podejście do seksu przedmałżeńskiego i pozamałżeńskiego. Im bardziej niezależna materialnie jest kobieta, tym częściej członkowie społeczeństwa zdają się nie dostrzegać jej pozamałżeńskich romansów. Macierzyństwo traktowała jako przywilej, a nie obowiązek kobiety, kwestionowała teorię na temat naturalnego pochodzenia instynktu macierzyńskiego. Twierdziła, że macierzyństwo jest organizowane w społeczeństwie w sposób mający na celu utrudnienie życia kobietom, choć najpierw zachęca się je do zostania matkami. W rezultacie, kobiety często zmuszone są dokonywać trudnych wyborów, pomiędzy urodzeniem dzieci a pracą zawodową.

38 Tamże, s. 537. 
Tak więc niezależna kobieta jest dziś rozdarta między zainteresowaniami zawodowymi a troską o swoje seksualne powołanie; trudno jej znaleźć równowagę, a jeśli ją znajduje, to kosztem ustępstw, poświęceń i niemal akrobatycznych wysiłków wymagających bezustannego napięcia ${ }^{39}$.

Filozofka opowiada się nad instytucjonalnym wspieraniem opieki rodzicielskiej i aktywizacją zawodową kobiet. Konieczne są tym samym zmiany w strukturach instytucjonalnych, aby pracujące matki otrzymywały pomoc w zakładach pracy, akcentując korzystny wpływ edukacji i pracy zawodowej kobiet na rozwój dzieci:

Kobieta o bogatym życiu osobistym może dać dziecku więcej z siebie, wymaga od niego mniej. A ta, która w wysiłku, w walce zdobywa wiedzę o prawdziwych wartościach ludzkich jest najlepszym pedagogiem ${ }^{40}$ - pisała.

Pielęgnowanie kobiecych przyjaźni i zjednoczenie wspólnotą interesów. S. de Beauvoir wiele uwagi poświęcała kobiecej przyjaźni, choć najbliższym jej przyjacielem był w zasadzie mężczyzna. Podkreślała, że tak cenione w okresie dzieciństwa dziewczęce przyjaźnie kończą się w momencie zamążpójścia i narodzin dzieci. Mężatka utrzymując je bowiem, odczuwa poczucie winy, że "trwoni czas” przeznaczony na prace domowe bądź kontakt z dziećmi.

Przyjaźń z kobietami, którą udało się mężatce zachować lub nawiązać jest czymś bardzo cennym. Przyjaźń między kobietami ma zupełnie inny charakter niż stosunki z mężczyznami; ci ostatni obcują ze sobą jako jednostki, poprzez swe osobiste idee i projekty, kobiety natomiast uwięzione w gatunkowości kobiecego losu, są złączone czymś w rodzaju immanentnej wspólnoty i szukają u siebie nawzajem potwierdzenia wspólnego świata. Nie dyskutują na temat poglądów, ale wymieniają zwierzenia i przepisy. Sprzymierzają się, aby stworzyć jakby antyświat, którego walory przeważyłyby walory męskie ${ }^{41}$.

Ten kobiecy antyświat może w pewnym momencie zaistnieć jako świat równoległy obok męskiego. Kobiety zjednoczone wspólnymi losami i doświadczeniami mogłyby wspierać się $\mathrm{w}$ drodze do wyzwolenia. Istotną rolę mogłyby odegrać tu intelektualistki bądź kobiety z wyższych sfer. Te jednak przeważnie poprzez przymierze z mężczyzną starają się zapewnić sobie lepszy los niż inne kobiety, dlatego też skłaniają się ku androcentrycznym normom ${ }^{42}$.

\footnotetext{
39 Tamże, s. 752.

40 Tamże, s. 584.

${ }^{41}$ Tamże, s. 502.

42 Tamże, s. 679.
} 
A więc mówienie o „kobiecie w ogóle” jest takim samym nonsensem, jak mówienie o wiecznym „mężczyźnie”. Nietrudno też zrozumieć, dlaczego jałowe są wszelkie próby rozstrzygnięcia, czy kobieta jest czymś wyższym, podrzędnym czy równym mężczyźnie. Rzecz w tym, że ich sytuacje są na wskroś odmienne ${ }^{43}$.

Odmienność sytuacji rodzi niezrozumienie pomiędzy kobietami a mężczyznami i konflikty.

Osiąganie niezależności ekonomicznej poprzez pracę zawodową. Wyłącznie praca, a raczej niezależność finansowa daje kobiecie wolność, jednak wolność ta nie jest możliwa jeśli kobieta jest wyzyskiwana na rynku pracy. Wiele kobiet osiąga tak niskie dochody i ma na tyle małą satysfakcję z pracy zawodowej, iż traktują ją tylko jako smutną konieczność, którą podejmują wyłącznie wówczas, kiedy mąż nie jest w stanie utrzymać rodziny. Praca zawodowa nie jest też źródłem satysfakcji, gdy po powrocie z niej kobiety samodzielnie sprawują obowiązki macierzyńsko-wychowawcze i podejmują prace domowe. Wówczas przeważnie traktują ją jako dodatkowe obciążenie i przykrą konieczność. Środkiem zaradczym na taką sytuację jest staranne kształcenie kobiet i rzetelne wynagradzanie wykonywanych przez nie prac (to może zapewnić właśnie praca na wysokich stanowiskach) oraz wspieranie instytucjonalne $\mathrm{w}$ wykonywaniu prac domowych i wychowaniu dzieci. S. de Beauvoir zauważa, że kobiety pracujące zawodowo mogą być wzorem osobowym dla pozostałych. Należy zapoznać się z ich sytuacją i problemami, a przy tym nagłaśniać pracę zawodową kobiet.

A jednak istnieje dziś sporo uprzywilejowanych kobiet, znajdujących w swoim zawodzie niezależność materialną i społeczną. O nich myślimy, gdy zastanawiamy się nad możliwościami i przyszłością kobiety. I właśnie dlatego - mimo, że takie kobiety są jeszcze mniejszością - zapoznanie się z ich sytuacją może być szczególnie interesujące; na ich właśnie temat toczą się długotrwałe debaty między feministami i antyfeministami. Pierwsi przesadnie oceniają uzyskane rezultaty i w zaślepieniu nie dostrzegają kobiecej rozterki, drudzy twierdzą, że dzisiejsze niezależne kobiety nie dokonują w świecie niczego ważnego, jednocześnie z trudem znajdując wewnętrzną równowagę. W istocie nic nie upoważnia do twierdzenia, jakoby te kobiety obrały fałszywą drogę; a przecież to prawda, że nie czują się jeszcze pewne w swojej nowej sytuacji - znajdują się dopiero $\mathrm{w}$ połowie drogi ${ }^{44}$.

Pracę zawodową uważa ona za pierwszy krok na drodze ku wyzwoleniu. Aby kobiety mogły osiągać sukcesy zawodowe, konieczna jest jeszcze zmiana mentalności społecznej, jak i samych kobiet, by kobieta wkraczała na rynek pracy bez poczucia winy i uwikłana w ciągły konflikt ról.

\footnotetext{
${ }^{43}$ Tamże.

${ }^{44}$ Tamże, s. 738.
} 
Ten właśnie konflikt jest szczególnie charakterystyczny dla sytuacji wyzwolonej kobiety. Nie chce ona tkwić w roli samicy, ponieważ nie chce się pozwolić okaleczyć, ale wyparcie się płci jest również okaleczeniem $\operatorname{się}^{45}$.

Nie kwestionuje kobiecości, lecz cechy utożsamiane z nią uważa za wpojone kulturowo. Proponuje kobietom obieranie zawodów utożsamianych kulturowo z męskością, związanych ze sprawowaniem władzy w świecie i wysokim prestiżem, przezwyciężanie własnych barier psychicznych oraz barier ekonomicznych, kulturowych, społecznych i mentalnych na drodze do własnego sukcesu. Wprawdzie łatwiej - jej zdaniem - kobiecie odnaleźć się w zawodach podkreślających własną esencję, to jest baletnicy, aktorki, tancerki, ale praca w nich nie przełamuje kulturowych stereotypów i nie prowadzi do przejmowania władzy.

Zmiana kulturowego sposobu myślenia o kobietach. Zarówno kobiety, jak i mężczyźni powinni zrozumieć, że sytuacja życiowa kobiet wypaczająca ich psychikę nie jest korzystna ani dla samych kobiet, ani dla mężczyzn. Nie sposób zbudować szczęśliwego związku ze zniewoloną osobą, w tym celu niezbędne jest równouprawnienie płci i wolność.

Człowiek winien zmienić zastany świat w królestwo wolności. To najwyższe zwycięstwo będzie niemożliwe, o ile między innymi mężczyźni i kobiety nie przejdą do porządku nad swym naturalnym zróżnicowaniem i nie utwierdzą jednoznacznie i zdecydowanie swojego braterstwa ${ }^{46}$.

Kobiety - jej zdaniem - zaczynają dążyć do uzyskania wolności, lecz urodzone i wychowane $\mathrm{w}$ patriarchacie nie potrafią na razie jej $\mathrm{w}$ odpowiedni sposób wykorzystać, by zrealizować swe cele i cele innych kobiet.

Wolność każdego człowieka jest całkowita, tyle że u kobiety jest abstrakcyjna i pusta, a więc może być autentycznie spełniona tylko przez bunt będący jedyną otwartą drogą dla tych, co nie mają możliwości budowania czegokolwiek. Muszą one odrzucić granicę swej sytuacji i dążyć do utorowania sobie drogi do przyszłości. Rezygnacja jest tylko poddaniem i ucieczką: dla kobiety nie ma innej drogi prócz własne wyzwolenie ${ }^{47}$.

Tylko wyzwolenie da jej ocalenie, uczyni ją bardziej interesującą dla siebie samej, mężczyzn, umożliwi wnoszenie nowych wartości w życie społeczne. Społeczeństwo stanie się inne, a życie w nim bardziej interesujące. Nie należy aprobować poglądów, że równość pomiędzy kobietą a mężczyzną powoduje nudę:

\footnotetext{
45 Tamże, s. 739.

46 Tamże, s. 782.

47 Tamże, s. 680.
} 
Mówiąc nawiasem, wydaje się zupełnym nonsensem twierdzenie, że przyszłemu światu grozi ujednolicenie, a więc nuda. Nie wydaje mi się, żeby w teraźniejszym świecie brak było nudy, ani że wolność może stworzyć jednostajnośćc ${ }^{4}$.

S. de Beauvoir przypisywała istotną rolę $\mathrm{w}$ drodze do wyzwolenia kobiet również mężczyznom. Zdawała sobie sprawę, że kobieta i mężczyzna potrzebują siebie wzajemnie, współistnieją obok siebie i dla siebie, potrzebują swego wsparcia w codziennym życiu. Mężczyzn również starała się przekonać, że kobiety wolne są bardziej interesujące, są ciekawszymi partnerami, lepszymi matkami. Pisząc o mężczyznach zauważała,

(...) gdyby się zgodzili kochać zamiast niewolnic równie wolne istoty, jak czynią to ci, którzy nie mają w sobie pychy ani kompleksu niższości, kobiety mniej obsesyjnie dążyłyby do kobiecości, zyskiwałyby na naturalności i prostocie, pozostając w efekcie kobietami bez nadmiernego trudu, skoro koniec końców i tak nimi są ${ }^{49}$.

\section{„Kto się dziś (nie)boi S. de Beauvoir"50? - zakończenie}

Dokonując analizy poglądów S. de Beauvoir zawartych w pracy Druga płeć, można zauważyć, iż większość spośród proponowanych przez nią reform społecznych została wdrożona. Pomimo to wokół samej postaci narosło tak wiele mitów i uprzedzeń, że jej filozofia rzadko bywa przywoływana w pracach naukowych. Analizując poglądy współczesnych socjologów bądź filozofów, można znaleźć te same tezy i propozycje zmian, które postulowała w latach czterdziestych de Beauvoir. Wiele tez odpowiadających filozofii słynnej egzystencjalistki napotkać można w pracy P. Bourdieu, zatytułowanej Męska dominacja ${ }^{51}$, do której zbliżona jest zwłaszcza krytyka różnicowania płciowego $\mathrm{w}$ trakcie procesu maskulinizacji i feminizacji, a także analiza sposobu funkcjonowania instytucji oddziałujących na struktury nieświadomości kobiet: rodziny, szkoły, kościoła i państwa ${ }^{52}$. Poglądy Bourdieu wskazujące na konwersje i akumulacje kapitału kobiety, rozważania na temat przemocy symbolicznej, heterodoksji i ortodoksji także zbliżone są do analiz sytuacji kobiet $\mathrm{S}$. de Beauvoir. Bourdieu powoływał się przy tym w swych pracach na osiągnięcia feministek francuskich, angielskich i amerykańskich, ceniąc osiągnięcia feminizmu ${ }^{53}$. W niedawno wydanej $\mathrm{w}$ Polsce książce

\footnotetext{
48 Tamże, s. 781.

49 Tamże, s. 742.

${ }^{50}$ Tytuł powstał przez analogię do sztuki E. Albee, zatytułowanej Kto się boi Virginii Wolf?

51 P. Bourdieu, Męska dominacja, Warszawa 2004, s. 102.

52 Tamże.

53 Tamże, s. 139.
} 
A. Giddensa ${ }^{54}$ odnaleźć można refleksje na temat miłości, erotyki i seksualizmu zbliżone do refleksji de Beauvoir. J. Baudrillard w książce $O$ uwodzeniu ${ }^{55}$ również korzysta $\mathrm{z}$ analiz kulturowego konstruowania cielesności kobiety zbliżonych do poglądów de Beauvoir. I choć sądzi on, że feministki nie mają racji odrzucając wykorzystanie swej urody w przejmowaniu władzy nad mężczyznami, co różni go od poglądów de Beauvoir zachęcającej kobiety do zapewnienia sobie pozycji równej mężczyznom poprzez wykorzystanie intelektu, niezależności ekonomicznej i angażowania się w sprawy kobiet, podobnie jak ona prowadzi dyskurs nad przejmowaniem władzy za pomocą ciała (choć de Beauvoir ocenia to krytycznie, a Baudrillard pozytywnie). Podobne przykłady można by mnożyć, zwłaszcza odwołując się do prac pisanych w obrębie konstruktywizmu społecznego. Trudno byłoby nie dostrzec wpływu tez postawionych przez de Beauvoir na rozwój współczesnych nauk społecznych, jak również humanistycznych. Jej prace rzadko podlegają jednak analizie badaczy, również z perspektywy feministycznej, choć Simone niewątpliwie można uznać za prekursorkę francuskiego feminizmu, to jej niezależne poglądy i otwarte horyzonty sprawiały, że nie identyfikowała się całkowicie z żadną ideologią - co wywoływało z kolei ataki ze strony feministek. W rezultacie, feminizm egzystencjalny $S$. de Beauvoir wyróżniony został przez R. Putan Tong jako odrębny nurt feminizmu ${ }^{56}$. Na gruncie nauk o wychowaniu prace de Beauvoir nie doczekały się analiz, pomimo iż przesłanie Drugiej płci wyraźnie można odczytać w perspektywie pedagogicznej. Czyżby kontrowersyjna Simone de Beauvoir budziła obawy w czasach, kiedy przesłanie jej prac kojarzy się nam raczej z łagodnymi postulatami ruchów emancypacyjnych? Nie sądzę. Wydaje mi się, że wynika to z narosłych wokół jej twórczości mitów i uprzedzeń, z którymi ona sama przez całe życie walczyła.

\section{BIBLIOGRAFIA}

Baudillard J., O uwodzeniu, Wyd. SIC! Warszawa 2005.

Bourdieu P., Męska dominacja, Oficyna Naukowa, Warszawa 2004.

De Beuvoir S., Pamiętnik statecznej panienki, Wydawnictwo Jacek Santorski, Warszawa 2002.

De Beauvoir S., Druga płeć, Wydawnictwo Jacek Santorski, Warszawa 2004.

Domagalik M., Przedmowa, [w:] S. de Beauvoir, Pamiętnik statecznej panienki, Wydawnictwo Jacek Santorski, Warszawa 2002.

${ }^{54}$ A. Giddens, Przemiany intymności: seksualność, miłość i erotyzm we wspótczesnych społeczeństwach, Warszawa 2006.

55 J. Baudillard, O uwodzeniu, Warszawa 2005.

${ }^{56}$ Klasyfikacje nurtów feminizmu przyjmuję i podaję za: R. Putan Tong, Myśl feministyczna - wprowadzenie, Warszawa 2005. 
Giddens A., Przemiany intymności: seksualność, miłość i erotyzm we współczesnych społeczeństwach, Wydawnictwo Naukowe PWN, Warszawa 2006.

Lipstiz-Bem S., Esencjalizm biologiczny, [w:] S. Lipstiz-Bem, Męskość, kobiecość. O różnicach wynikających z ptci, Gdańskie Wydawnictwo Psychologiczne, Gdańsk 2000.

Murzyn A., Simone de Beauvoir. Filozofia a płeć, Oficyna Wydawnicza Impuls, Kraków 1999. Nasiłowska A., Jean Paul Sartre i Simone de Beauvoir, Wydawnictwo Literackie, Kraków 2006.

Putan Tong R., Myśl feministyczna - wprowadzenie, Wydawnictwo Naukowe PWN, Warszawa 2005.

Rowley H., Tete a tete. Opowieść o Simone de Beauvoir i Jean Paulu Sartrze, Wydawnictwo Jacek Santorski, Warszawa 2006.

Schwarzer A., Simone de Beauvoir, Chatto \& Windus 1990. 